\title{
RASIONALITAS PENGGUNAAN ANTIBIOTIKA PADA PASIEN POLI GIGI SALAH SATU RUMAH SAKIT PENDIDIKAN DI JAKARTA
}

\author{
Pinka Taher*, Poetry Oktanauli*, Siti Riskia Anggraini** \\ *Departemen Oral Biologi, Fakultas Kedokteran Gigi Universitas Prof. Dr. Moestopo (Beragama), Jakarta \\ **Fakultas Kedokteran Gigi Universitas Prof. Dr. Moestopo (Beragama), Jakarta \\ Korespondensi: Pinka Taher, pinka.taher@gmail.com
}

\begin{abstract}
ABSTRAK
Latar belakang: penggunaan antibiotika sebagai terapi dasar dalam penyakit infeksi harus dilakukan secara bijak dan rasional. Penggunaan antibiotika yang rasional adalah penggunaan antibiotika yang tepat dalam hal diagnosis, indikasi penyakit, pemilihan obat, dosis obat, cara pemberian, interval waktu pemberian, lama pemberian, penilaian kondisi pasien, serta waspada terhadap efek samping. Penggunaan antibiotika yang tidak rasional dapat menyebabkan peningkatan biaya pengobatan, risiko terjadinya efek samping obat, dan juga resistensi antibiotika. Tujuan: penelitian ini bertujuan untuk mengetahui rasionalitas penggunaan antibiotika pada pasien poli gigi salah satu rumah sakit pendidikan di Jakarta. Metode: penelitian ini merupakan penelitian observasional deskriptif yang bersifat retrospektif, datanya diambil dari 60 rekam medis yang memuat pemberian resep antibiotika pada pasien poli gigi salah satu rumah sakit pendidikan di Jakarta periode Juni-Juli 2019. Data penelitian yang diperoleh dianalisis menggunakan kriteria Gyssens dkk. Hasil: penggunaan antibiotika pada penelitian ini yang rasional sebesar $68,3 \%$, sedangkan yang tidak rasional terdiri dari $15 \%$ disebabkan oleh adanya antibiotika lain yang kurang toksik atau lebih aman, $10 \%$ disebabkan oleh adanya antibiotika lain yang lebih efektif dan 6,7\% disebabkan oleh penggunaan antibiotika tanpa indikasi. Kesimpulan: penggunaan antibiotika yang rasional pada pasien poli gigi salah satu rumah sakit pendidikan di Jakarta sebesar $68,3 \%$.
\end{abstract}

Kata kunci: antibiotika, rasional, Gyssens

\begin{abstract}
Background: The use of antibiotics as a basic therapy in infectious diseases must be done wisely and rationally. The rational use of antibiotics is the correct use of antibiotics in terms of diagnosis, disease indication, drug selection, drug dosage, method of administration, time interval of administration, duration of administration, assessment of the patient's condition, and awareness of side effects. The irrational use of antibiotics will lead to increased medical costs, the risk of drug side effects, and also antibiotic resistance. Purpose: This study aims to determine the rationality of antibiotics usage in the dental clinic's patients of a teaching hospital in Jakarta. Method: This study was a retrospective descriptive observational, in which data were taken from 60 medical records containing prescription of antibiotics for patients in the dental clinic of a teaching hospital in Jakarta for the period June-July 2019. The data obtained were then analyzed using Gyssens et all criteria. Results: In this study, the rational use of antibiotics was $68.3 \%$, while the irrational use of antibiotics consisted of $15 \%$ due to the presence of other antibiotics that were less toxic or safer, $10 \%$ due to the presence of other antibiotics that were more effective and $6.7 \%$ caused by the use of antibiotics without indication. Conclusion: The rationality of antibiotics usage in dental clinic's patients of a teaching hospital in Jakarta is $68.3 \%$.
\end{abstract}

Keywords: antibiotics, rational, Gyssens

\section{PENDAHULUAN}

$\mathrm{A}$ ntibiotika merupakan salah satu obat yang paling sering digunakan dalam kedokteran gigi. Antibiotika digunakan untuk mengobati berbagai infeksi jaringan keras maupun jaringan lunak dalam rongga mulut. Penggunaan antibiotika haruslah dilakukan secara cermat dan rasional. Hal ini disebabkan penggunaan obat yang tidak cermat 
dan rasional dapat menyebabkan berbagai kerugian bagi pasien dan masyarakat, antara lain peningkatan biaya pengobatan, risiko terjadinya efak samping bahkan toksisitas obat, dan juga terjadinya resistensi obat. ${ }^{1,2}$

Penggunaan antibiotika yang rasional harus memenuhi beberapa persyaratan, antara lain: (1) berdasarkan diagnosis yang tepat, (2) sesuai indikasi penggunaan obat, (3) tepat dalam pemilihan obat, dosis obat, pemilihan rute pemberian obat, penentuan interval waktu dan lama pemberian obat, (4) berdasarkan penilaian kondisi pasien secara individual, dan (5) waspada terhadap risiko terjadinya efek samping obat. $^{2}$ Penggunaan antibiotika tidak rasional yang sering terjadi adalah penggunaan antibiotika untuk penyakit yang sebenarnya tidak memerlukan antibiotika, penggunaan hanya satu golongan antibiotika untuk infeksi polimikrobial yang disebabkan oleh kuman aerob dan anaerob, pemberian dosis yang tidak adekuat dan penggunaan antibiotika yang tidak memperhatikan kondisi pasien sehingga meningkatkan risiko toksisitas obat. ${ }^{1}$

Berbagai penelitian yang dilakukan di negara maju dan berkembang menunjukkan bahwa lebih dari separuh penggunaan antibiotika di dunia dilakukan secara tidak rasional. The Center for Disease Control and Prevention di Amerika menyebutkan bahwa ditemukan 50 juta pemberian resep antibiotika yang tidak rasional dari 150 juta pemberian resep antibiotika setiap tahunnya. ${ }^{3}$ Demikian juga dengan penggunaan antibiotika di Indonesia, pemberian resep antibiotika yang tidak rasional ditemukan di banyak rumah sakit dan pusat kesehatan masyarakat. Sekitar 40-62\% antibiotika di Indonesia digunakan secara tidak rasional untuk kasus-kasus yang seharusnya tidak memerlukan antibiotika. Penilaian penggunaan antibiotika secara rasional di RSUD Dr. Soetomo Surabaya dan RSUP Dr. Karyadi Semarang yang mewakili rumah sakit pendidikan di Indonesia, menunjukkan bahwa 30-80\% penggunaan antibiotika tidak didasarkan pada indikasi yang tepat. ${ }^{4}$

Berdasarkan penjelasan latar belakang di atas, maka penelitian ini dilakukan untuk mengetahui rasionalitas penggunaan antibiotika pada pasien poli gigi salah satu rumah sakit pendidikan di Jakarta.

\section{METODE PENELITIAN}

Penelitian observasional deskriptif ini dilakukan secara retrospektif terhadap data rekam medis yang memuat pemberian resep antibiotika untuk pasien poli gigi salah satu rumah sakit pendidikan di Jakarta. Sampel penelitian diambil dengan metode total sampling, sehingga didapatkan sampel sebanyak jumlah keseluruhan pasien yang menerima resep antibiotika periode Juni-Juli 2019. Total sampel yang diperoleh adalah 60 rekam medis, dihitung berdasarkan rumus Lemeshow. ${ }^{5}$

Data sekunder yang berhasil dihimpun memuat: anamnesis pasien, demografi (umur, jenis kelamin), diagnosis penyakit, nama antibiotika, frekuensi, durasi dan rute atau cara pemberian antibiotika. Selanjutnya data ini dianalisis menggunakan kriteria Gyssens dkk. Kriteria Gyssens dkk merupakan suatu metode untuk mengevaluasi kualitas penggunaan antibiotika yang telah digunakan secara luas di berbagai negara. ${ }^{6}$ Penilaian rasionalitas penggunaan antibiotika menggunakan kriteria atau klasifikasi Gyssens dkk terbagi dalam kategori, sebagai berikut: ${ }^{6,7.8 .9 .10}$

$$
\begin{aligned}
& \text { Kategori } 0=\text { penggunaan antibiotika tepat atau } \\
& \text { rasional } \\
& \text { Kategori I = penggunaan antibiotika tidak tepat } \\
& \text { waktu }
\end{aligned}
$$

Alur penilaian rasionalitas penggunaan antibiotika berdasarkan kriteria Gyssens dkk dapat dilihat pada gambar $1 .^{9}$ 


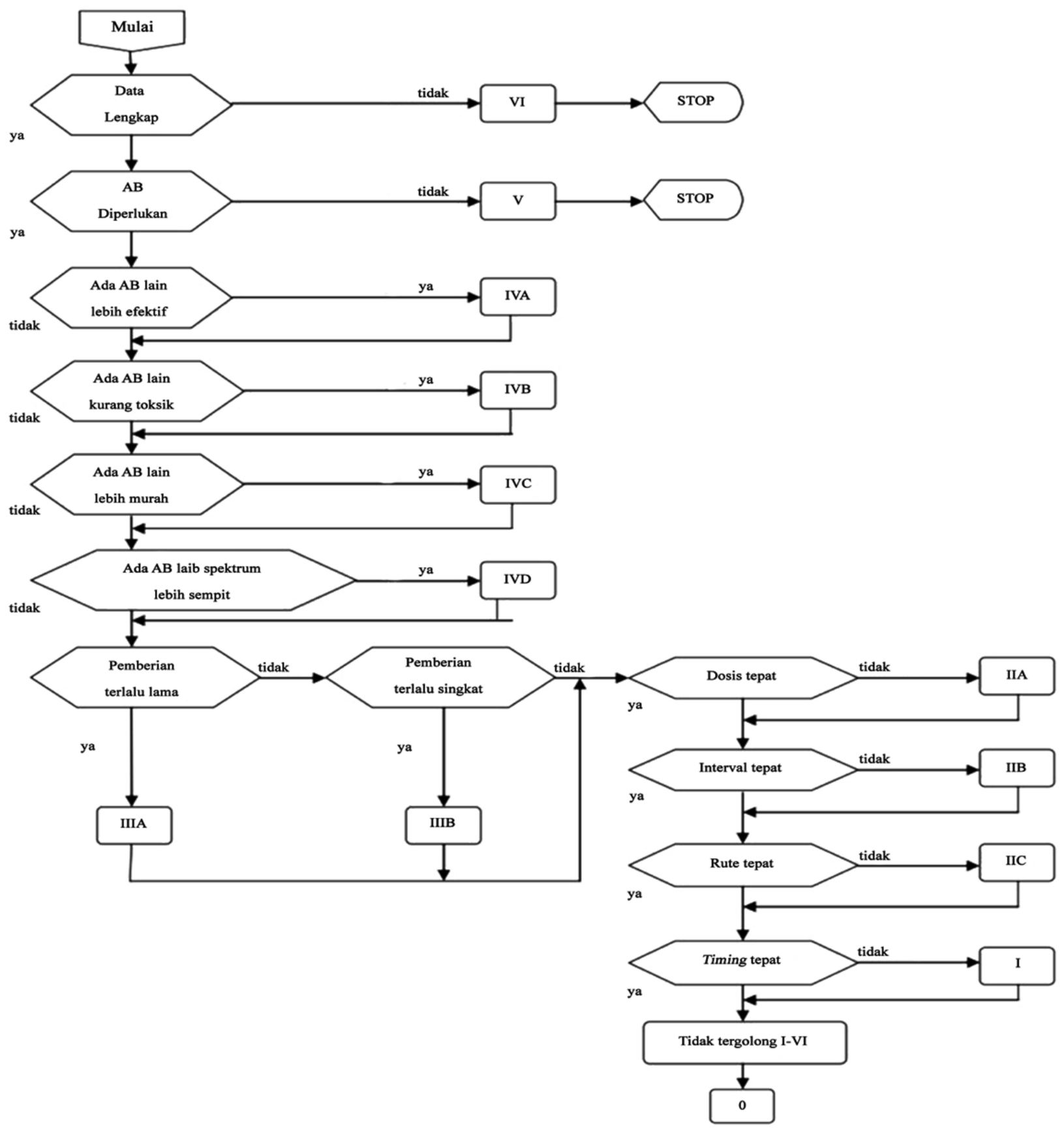

Gambar 1. Alur Penilaian Kualitatif Penggunaan Antibiotika menurut Gyssens dkk ${ }^{9}$

Penilaian rasionalitas penggunaan antibiotika menurut Gyssens dkk dimulai dari kotak paling atas, yaitu melihat lengkap tidaknya data untuk melanjutkan penilaian. Bila data tidak lengkap, penilaian berhenti di kategori VI. Data tidak lengkap adalah data rekam medis tanpa disertai diagnosis penyakit, atau ada halaman rekam medis yang hilang sehingga tidak dapat dievaluasi. Bila data lengkap, dilanjutkan dengan penilaian ada tidaknya indikasi pemberian antibiotika. Bila tidak ada indikasi pemberian antibiotika, penilaian berhenti di kategori V. Bila antibiotika memang merupakan indikasi, dilanjutkan dengan penilaian ketepatan pemilihan antibiotika. Bila ada pilihan antibiotika lain yang lebih efektif, penilaian berhenti di kategori IVa. Bila tidak ada antibiotika lain yang lebih efektif, dilanjutkan dengan penilaian ada tidaknya alternatif antibiotika lain yang kurang toksik. Bila ada pilihan antibiotika lain yang kurang toksik, penilaian berhenti di kategori IVb. Bila tidak ada antibiotika lain yang kurang toksik, dilanjutkan dengan penilaian ada tidaknya alternatif antibiotika lain yang lebih murah. Bila ada pilihan antibiotika lain yang lebih murah, penilaian berhenti di kategori IVc. Penilaian ini berpatokan pada daftar harga obat yang dikeluarkan oleh Rumah Sakit Cipto Mangunkusumo dan semua antibiotika dihitung harganya sebagai obat generik. 
Bila tidak ada antibiotika lain yang lebih murah, dilanjutkan dengan penilaian ada tidaknya alternatif antibiotika lain yang spektrumnya lebih sempit. Bila ada pilihan antibiotika lain dengan spektrum lebih sempit, penilaian berhenti di kategori IVd. Jika tidak ada antibiotika lain yang memiliki spektrum antimikroba lebih sempit, dilanjutkan dengan penilaian durasi pemberian antibiotika. Bila durasi pemberian antibiotika terlalu lama, penilaian berhenti di kategori IIIa. Bila durasi pemberian antibiotika tidak terlalu lama, dilanjutkan dengan penilaian durasi pemberian antibiotika tidak terlalu singkat. Bila durasi pemberian antibiotika terlalu singkat, penilaian berhenti di kategori IIIb. Bila durasi pemberian antibiotika tidak terlalu singkat, diteruskan dengan penilaian ketepatan pemberian dosis antibiotika. Bila dosis pemberian antibiotika tidak tepat, penilaian berhenti di kategori IIa. Bila dosisnya sudah tepat, dilanjutkan dengan penilaian ketepatan interval pemberian antibiotika. Bila interval pemberian antibiotika tidak tepat, penilaian berhenti di kategori IIb. Bila intervalnya sudah tepat, dilanjutkan dengan penilaian ketepatan rute pemberian antibiotika. Bila rute pemberian antibiotika tidak tepat, penilaian berhenti di kategori IIc. Bila rute sudah tepat, dilanjutkan ke kotak berikutnya. Bila antibiotika tidak termasuk kategori I sampai dengan VI maka antibiotika tersebut merupakan kategori $0 .{ }^{9}$

\section{HASIL PENELITIAN}

Golongan antibiotika yang terdapat dalam 60 rekam medis ini dapat dilihat pada tabel 1 . Tabel 1 menunjukkan bahwa golongan antibiotika yang paling banyak digunakan pada penelitian ini adalah penisilin yaitu $68,3 \%$, diikuti dengan golongan linkosamid $30 \%$.

Tabel 1. Golongan Antibiotika

\begin{tabular}{ccc}
\hline $\begin{array}{c}\text { Golongan } \\
\text { Antibiotika }\end{array}$ & Frekuensi & Persentase (\%) \\
\hline Penisilin & 41 & $68,3 \%$ \\
Linkosamid & 18 & $30 \%$ \\
Sefalosporin & 1 & $1,7 \%$ \\
\hline
\end{tabular}

Berbagai kategori kriteria Gyssens dkk dari tiap golongan antibiotika berdasarkan diagnosis penyakit dapat dilihat pada tabel 2 .

Tabel 2. Penggunaan Antibiotik Berdasarkan Diagnosis Penyakit Menurut Kriteria Gyssens dkk

\begin{tabular}{|c|c|c|c|c|c|c|}
\hline \multirow{2}{*}{ Diagnosis-Terapi } & \multirow{2}{*}{ Antibiotika } & \multirow{2}{*}{ Frekuensi } & \multicolumn{4}{|c|}{ Kategori } \\
\hline & & & $\mathbf{0}$ & IVA & IVB & $\mathbf{V}$ \\
\hline \multirow{3}{*}{$\begin{array}{l}\text { Gangren pulpa, +pulpa polip, +abses - } \\
\text { Trepanasi/ Exo/PSA/medisasi }\end{array}$} & Penisilin & 20 & 20 & 0 & 0 & 0 \\
\hline & Linkosamid & 2 & 0 & 0 & 2 & 0 \\
\hline & Sefalosporin & 1 & 0 & 1 & 0 & 0 \\
\hline \multirow{2}{*}{ Gangren radiks - Exo } & Penisilin & 5 & 5 & 0 & 0 & 0 \\
\hline & Linkosamid & 1 & 0 & 0 & 1 & 0 \\
\hline \multirow{2}{*}{ Abses - Insisi/medisasi } & Penisilin & 4 & 4 & 0 & 0 & 0 \\
\hline & Linkosamid & 2 & 2 & 0 & 0 & 0 \\
\hline \multirow{2}{*}{ Perikoronitis - Operkulektomi } & Penisilin & 1 & 1 & 0 & 0 & 0 \\
\hline & Linkosamid & 2 & 0 & 0 & 2 & 0 \\
\hline \multirow{2}{*}{$\begin{array}{c}\text { Periodontitis }- \text { Scaling + root planing / } \\
\text { medisasi }\end{array}$} & Penisilin & 1 & 0 & 1 & 0 & 0 \\
\hline & Linkosamid & 4 & 0 & 4 & 0 & 0 \\
\hline \multirow{2}{*}{ Pulpitis kronis - Exo } & Penisilin & 4 & 4 & 0 & 0 & 0 \\
\hline & Linkosamid & 4 & 0 & 0 & 4 & 0 \\
\hline Hiperemi pulpa - Filling & Penisilin & 2 & 0 & 0 & 0 & 2 \\
\hline Gingivitis - Scaling & Penisilin & 2 & 0 & 0 & 0 & 2 \\
\hline \multirow{2}{*}{ Impaksi - Odontektomi } & Penisilin & 2 & 2 & 0 & 0 & 0 \\
\hline & Linkosamid & 3 & 3 & 0 & 0 & 0 \\
\hline
\end{tabular}


Tabel 3 memuat kategori kriteria Gyssens dkk dari tiap golongan antibiotika yang digunakan pada penelitian ini. Pada tabel ini dapat dilihat bahwa golongan penisilin yang paling banyak digunakan secara rasional yaitu 36 dari 41 kasus (88\%), sedangkan golongan linkosamid sebanyak 5 dari 18 kasus (28\%) dan golongan sefalosporin tidak ada yang memenuhi kategori 0.

Tabel 3. Kategori Kriteria Gyssens dkk dari Tiap Golongan Antibiotika

\begin{tabular}{cccccc}
\hline \multirow{2}{*}{$\begin{array}{c}\text { Golongan } \\
\text { Antibiotika }\end{array}$} & \multicolumn{4}{c}{ Kriteria Gyssens dkk } & \multirow{2}{*}{ Total } \\
\cline { 2 - 5 } & $\mathbf{0}$ & IVA & IVB & V & \\
\hline Penisilin & 36 & 1 & 0 & 4 & 41 \\
Lincosamide & 5 & 4 & 9 & 0 & 18 \\
Sefalosporin & 0 & 1 & 0 & 0 & 1 \\
\hline
\end{tabular}

Kategori kriteria Gyssens dkk dari seluruh penggunaan antibiotika pada penelitian ini dapat dilihat pada tabel 4 dan menunjukkan bahwa penggunaan antibiotika kategori 0 (penggunaan antibiotika tepat atau rasional) sebanyak 68,3\%, kategori IVA (ada antibiotika lain yang lebih efektif) sebanyak 10\%, kategori IVB (ada antibiotika lain yang kurang toksik atau lebih aman) sebanyak $15 \%$, dan kategori $\mathrm{V}$ (penggunaan antibiotika tanpa indikasi) sebanyak $6,7 \%$.

Tabel 4. Kategori Kriteria Gyssens dkk

\begin{tabular}{ccc}
\hline Kriteria Gyssens dkk & Frekuensi & Persentase\% \\
\hline Kategori 0 & 41 & $68,3 \%$ \\
Kategori IVA & 6 & $10 \%$ \\
Kategori IVB & 9 & $15 \%$ \\
Kategori V & 4 & $6,7 \%$ \\
\hline
\end{tabular}

\section{PEMBAHASAN}

Penggunaan antibiotika di poli gigi salah satu rumah sakit pendidikan di Jakarta pada penelitian ini yang rasional sebesar $68,3 \%$, dengan $88 \%$ antibiotika yang rasional adalah penisilin. Penggunaan antibiotika yang rasional adalah penggunaan antibiotika yang memenuhibeberapa kriteria, antara lain hanya diberikan untuk pasien dengan gejala infeksi. ${ }^{11,12}$ Penisilin pada penelitian ini hanya diberikan untuk kasus-kasus infeksi gigi yaitu gangren pulpa, gangren radiks, perikoronitis dan gigi impaksi, sehingga memenuhi kriteria penggunaan yang rasional. Kriteria berikutnya yaitu tepat pemilihan obat, pemberian antibiotika pada kasus infeksi harus mempertimbangkan faktor jenis mikroorganisme penyebab infeksi dan kepekaan mikroorganisme tersebut terhadap antibiotika yang diberikan. ${ }^{11,12}$ Infeksi odontogenik merupakan infeksi polimikrobial yang disebabkan oleh banyak spesies bakteri berbeda, baik gram positif maupun gram negatif. ${ }^{13,14,15}$ Golongan penisilin yang diberikan di penelitian ini adalah amoksilin. Amoksilin memiliki spektrum antimikroba luas (broad spectrum) yang aktif terhadap bakteri gram positif dan negatif. ${ }^{11,12,13}$ Jadi pemberian amoksilin pada penelitian ini adalah rasional. Kriteria berikutnya adalah tepat dosis, interval dan lama pemberian, karena pemberian dosis obat yang berlebihan dapat berisiko menimbulkan efek samping, begitupun sebaliknya pemberian dosis obat yang terlalu kecil dapat menyebabkan tidak tercapainya efek terapi yang diharapkan. ${ }^{11,12}$ Pada penelitian ini amoksilin digunakan dengan dosis 250-500 mg 3 kali sehari selama 3-5 hari. Hal ini sudah sesuai dengan dosis lazim penisilin. ${ }^{13,14}$ Kriteria berikutnya adalah tepat cara pemberian obat, beberapa antibiotika tidak dapat diberikan secara oral karena dirusak oleh asam lambung. Pada penelitian ini amoksilin merupakan antibiotika yang tepat diberikan secara oral, karena proses absorpsinya sangat baik bahkan dapat diberikan bersama-sama dengan makanan. ${ }^{12,13}$ Kriteria berikutnya adalah tepat penilaian kondisi pasien, yaitu pemberian obat harus sesuai dengan kondisi pasien berdasarkan riwayat sistemik atau keluarga pasien. Pasien-pasien yang memiliki penyakit sistemik seperti diabetes melitus, gangguan sistem kekebalan tubuh seperti $\mathrm{HIV}$, atau pasien yang mendapat terapi imunosupresan harus diberikan antibiotika yang memiliki aktivitas bakterisid. Amoksilin merupakan antibiotika yang memiliki aktivitas bakterisid sehingga dapat diberikan pada pasien-pasien dengan kondisi tersebut. ${ }^{11,13}$ Kriteria berikutnya adalah waspada terhadap efek samping, dalam hal ini toksisitas golongan penisilin relatif rendah, kecuali untuk reaksi alergi. Insidensi reaksi alergi penisilin hanya 1-5\%, sekalipun penisilin sendiri merupakan salah satu golongan antibiotika yang paling aman. ${ }^{12}$

Penelitian juga menunjukkan bahwa 10\% penggunaan antibiotika di poli gigi rumah sakit pendidikan ini termasuk dalam Kriteria Gyssens dkk kategori IVA, yang berarti penggunaan antibiotika tidak rasional karena adanya antibiotika lain yang lebih efektif. Sebagian besar kategori IVA ini berasal dari penggunaan antibiotika golongan linkosamid, yaitu klindamisin pada kasus periodontitis dan terdapat satu penggunaan antibiotika golongan sefalosporin, yaitu cefadroxil pada kasus pencabutan. Pada kasus periodontitis, obat antibiotika yang efektif digunakan adalah antibiotika golongan tetrasiklin seperti doksisiklin. ${ }^{13,14,15}$ Hal ini disebabkan mekanisme kerja tetrasiklin yang dapat menghambat sintesis dan pelepasan kolagenase (sebagai antikolagenase) dari leukosit polimorfonuklear (PMNs). Enzim kolagenase ini merusak dan memecah kolagen yang ada pada jaringan periodontal (gingiva, tulang, ligamen periodontal). Doksisiklin mempunyai aktivitas 
antikolagenase terbesar. Doksisiklin $20 \mathrm{mg}$ digunakan dalam penatalaksanaan periodontitis kronis generalis, disertai tindakan skeling dan root planing untuk mendapatkan perlekatan pada jaringan periodonsium dan mengurangi kedalaman probing. ${ }^{15}$ Penggunaan klindamisin pada kasus periodontitis di penelitian ini tidak rasional, walaupun klindamsin merupakan antibiotika spektrum sempit yang efektif terhadap sebagian besar bakteri gram positif dan anaerob, namun tidak memiliki aktivitas antikolagenase seperti doksisiklin. Penggunaan sefalosporin pada kasus pencabutan gigi di penelitian ini tidak rasional, disebabkan sefalosporin bukan merupakan obat pilihan utama untuk infeksi gigi karena kemampuan permeabilitas yang kurang terhadap bakteri penyebab infeksi gigi. Selain itu, spektrum sefalosporin yang luas tidak membuatnya lebih unggul dibandingkan efektivitas penisilin $\mathrm{V}$ untuk bakteri patogen odontogenik utama. ${ }^{15}$

Penelitian ini juga mendapati 15\% penggunaan antibiotika termasuk dalam kriteria Gyssens dkk kategori IVB, yang berarti penggunaan antibiotika tidak rasional karena ada antibiotika lain yang kurang toksik atau lebih aman. Salah satu alasan penggunaan golongan penisilin sebagai pilihan antibiotika lini pertama adalah aman dari efek samping, kecuali reaksi alergi. ${ }^{12}$ Pada penelitian ini sebagian besar kategori IVB berasal dari pemberian resep klindamisin yang masih digunakan sebagai antibiotika lini pertama pada kasus pencabutan ringan. Salah satu faktor yang membatasi penggunaan klindamisin adalah banyaknya efek samping yang dapat disebabkan oleh obat ini, antara lain: mual, muntah, diare, nyeri perut, ruam pada kulit, kolitis pseudomembranosis, Stevens Johnson Syndrome, granulositopenia (konsentrasi sel darah putih yang rendah) dan esofagitis. ${ }^{12,13}$

Penelitian ini juga menunjukkan sebanyak $6,7 \%$ penggunaan antibiotika termasuk dalam kriteria Gyssens dkk kategori V, yang berarti penggunaan antibiotika tidak rasional karena penggunaan antibiotika tidak diperlukan atau tidak sesuai dengan indikasi penyakit. Terdapat empat kasus yang tidak memerlukan pemberian antibiotika, namun menerima pemberian resep antibiotika. Keempat kasus tersebut adalah dua kasus hiperemi pulpa dan dua kasus gingivitis. Gingivitis memang disebabkan oleh infeksi bakteri, namun belum ada literatur yang mendukung penggunaan antibiotika sistemik pada gingivitis. Hal ini disebabkan infeksi tersebut umumnya terlokalisir pada permukaan gingiva yang kedalamannya dangkal sehingga mudah dirawat serta bersifat reversibel. ${ }^{11}$

\section{KESIMPULAN DAN SARAN}

Penggunaan antibiotika di poli gigi salah satu rumah sakit pendidikan di Jakarta yang rasional adalah sebesar 68,3\%. Sedangkan penggunaan antibiotika yang tidak rasional disebabkan oleh adanya pilihan antibiotika lain yang lebih aman sebesar $15 \%$, pilihan antibiotika lain yang lebih efektif sebesar $10 \%$ dan penggunaan antibiotika tanpa indikasi sebesar $6,7 \%$.

\section{DAFTAR PUSTAKA}

1. Suardi HN. Antibiotika dalam Dunia Kedokteran Gigi. Cakradonya Dent J. 2014; 6 (2): 678-744.

2. Kementrian Kesehatan Republik Indonesia (Kemenkes RI). Modul Penggunaan Obat Rasional. Jakarta: Kementrian Kesehatan Republik Indonesia. 2011.

3. Center for Disease Control and Prevention. Antibiotic Resistence Threats in The United States. United States: U.S. Department of Health and Human Services. 2013.

4. Kementrian Kesehatan Republik Indonesia (Kemenkes RI). Pedoman Umum Penggunaan Antibiotika. Jakarta: Kementrian Kesehatan Republik Indonesia. 2013.

5. Notoatmodjo S. Metodologi Penelitian Kesehatan. Jakarta: Rineka Cipta. 2010: 124-7.

6. Sitompul F, Radji M, Bahtiar A. Evaluasi Penggunaan Antibiotik dengan Metode Gyssens pada Pasien Stroke Rawat Inap di RSUD Koja secara Retrospektif. Jurnal Kefarmasian Indonesia. 2016; 6 (1) Feb: 30-38.

7. Sumiwi SA. Kualitas Penggunaan Antibiotik pada Pasien Bedah Digestif di Salah Satu Rumah Sakit di Bandung. Jurnal Farmasi Klinik Indonesia. 2014; 3 (4):135-140.

8. Indriani $\mathrm{L}$ dan Zunnita $\mathrm{O}$. Penilaian Terhadap Rasioanalitas Penggunaan Antibiotika Pada Balita Penderita Pneumonia Puskesmas Bogor Utara. Fitofarmaka Jurnal Ilmiah Farmasi. 2018; 8 (2) Desember: 92-99.

9. Faizah AK dan Putra ON. Evaluasi Kualitatif Terapi Antibiotik pada Pasien Pneumonia di Rumah Sakit Pendidikan Surabaya Indonesia. Jurnal Sains Farmasi \& Klinis. 2019; 6(2) Agustus: 129-133

10. Patminingsih N, Laksmitawati DR, Ramadaniati HU. Evaluasi Penggunaan Antibiotika Pada Pengobatan Sepsis Neonatal Dengan Metoda Gyssens di RSAD Salak Bogor Tahun 2018. Jurnal Ilmiah Indonesia. 2020; 5 (7): 381-397.

11. Katzung BG, Masters SB, Trevor AJ. Basic \& Clinical Pharmacology $12^{\text {th }}$ ed. Toronto: Mc Graw Hill Medical. 2012: 790-820.

12. Brunton LL, Dandan RH, Knollmann BC. Goodman \& Gilman's The Pharmacological Basis of Therapeutics $13^{\text {th }}$ ed. Toronto: Mc Graw Hill Education. 2018: 962965, 1023-37, 1049-58.

13. Dowd FJ, Johnson BS, Mariotti AJ. Pharmacology And Therapeutics For Dentistry $7^{\text {th }}$ ed. Missouri: Elsevier. 2017: 462-480

14. Troeltzsch M. A Review of Pathogenesis, Diagnosis, Treatment Options, and Differential Diagnosis of Odontogenic Infections: A Rather Mundane Pathology. Quentessence International General Dentistry. 2015; 46: 351-361.

15. Weinberg M, Froum SJ. Buku Panduan Kedokteran Gigi: Obat dan Pemberian resep (The Dentist's Drug and Prescription Guide). Lilian J (penerjemah), Melanie S (penyunting, penerjemah). Jakarta: EGC. 2018: 58-79, 160-185, 279. 